\title{
Evaluation Study of Some Imported Mango Cultivars Grown under Aswan Governorate Conditions
}

\author{
Ahmed, Y.Mohamed, Khaled A. Roshdy and Mohamed A.F. Badran ${ }^{1}$
}

\section{ABSTRACT}

During 2012 and 2013 seasons, five imported mango cultivars(cvs) Kent, Keitt, Tommy Atkins, Heidi and Naomi were grown in Aswan region and namely evaluated for their growth, yield and fruit characteristics. Great variations were observed on growth and fruiting characteristics among the five mango cvs. Based on relatively better yield and fruit quality, mango cvs Keitt, Tommy Atkins and Kent are suggested to be cultivated successfully in descending order under Aswan conditions.

Keywords: mango cvs, growth, fruiting

\section{INTRODUCTION}

Most cultivated fruit species posses numerous recognized cultivars and their productivity largely depends on the successful performance of the most popularly established planted cultivars. Different cultivars of mango varied in their performance and these differences are governed by various genetic, cultural and environmental factors. Due to the variation in performance of different mango cultivars, the suitability of these cultivars from the consumers point of view are often evaluated from different angles. A study of growth, yield and pomologically important external and internal characteristics of the fruit in mango cultivars is required to provide the important criteria for the evaluation of such cultivars.

The results of Ahmed (2002). Tawfik (2003). Nilesh and Banik (2005). Abd El- Hadi(2006). Zaied et al. (2006).Rao and Rao (2007) and Swidan et al. (2007) confirmed the importance of evaluation studies on improving the productivity of different mango cvs grown under various climates. Previous studies emphasized the beneficial effects of evaluation studies for selecting the best mango cvs for the various locations for obtaining the highest yield (Sayed, 2009, Shaban, 2009; El- Sheikh and Burshaid, 2010; Jilani, et al., 2010; Masoud - Amal, 2010; Pawan and Surendra, 2011; Reddy et al., 2011; Pawan et al., 2011; Abourayya et al., 2011 and 2012 Wang et al., 2013; Safuna et al., 2014 and Fahmy, 2016).

This study was established as an attempt to know more information about growth, flowering, fruit setting, yield and fruit quality of some mango cultivars growing under Aswan region conditions. This assessment could provide valuable information to prescribe the prime mango cvs. having higher yield and fruit quality which can be cultivated successfully under upper Egypt environmental conditions especially in Aswan region.

\section{MATERIALS AND METHODS}

This study was established during two consecutive seasons of 2012 and 2013 in a private orchard situated at Wady el- Nokra Aswan, Aswan governorate where the texture of the soil is sandy with a water table depth not less than two meters. Five mango cvs Kent, Keitt, Tommy Atkins, Heidi and Naomi were selected for achieving this evaluation study. Trees of all mango cvs were 10- years old at the start of this study. Trees were budded on mango seedling rootstocks. And were planted at $6 \times 6$ meters apart. Each cultivar was represented by six trees which were uniform in vigor.

Five treatments consisted of the five tested mango cultivars namely Kent, Keitte, Tommy Atkins, Heidi and Naomi were examined. This experiment was arranged in randomized complete block design (RCBD) with three replicates, two trees per each.

All mango cvs. received a basal recommended fertilizer in addition to the regular agricultural and horticultural practices which were already followed in the orchard including pruning, hoeing, irrigation with Nile water as well as pathogens, pests and weed control. The results of the orchard soil analysis according to Wilde et al. (1985) are shown in Table (1)

Monthly minimum and maximum temperatures as well as relative humidity percentages for Aswan governorate during 2012 and 2013 seasons were obtained and the data are shown in Table (2).

Generally, the following measurements for all the investigated mango cvs were recorded during the two seasons of the study.

Measurements of growth aspects in the growth cycles:

Ten secondary branches with 1.5 diameter were labeled in Feb. for each tree. Twenty new shoots in the growth flush were chosen from the ten labeled secondary branches per tree in all the investigated mango cvs. to measure their length $(\mathrm{cm}$.) and to count the number of leaves on them. Twenty leaves per shoot below panicles were taken for calculating their area $\left(\mathrm{cm}^{2}\right)$. Leaf area was measured using the following equation as reported by Ahmed and Morsy (1999). 
Table 1. Mechanical, physical and chemical analysis of the tests orchard soil

\begin{tabular}{|c|c|}
\hline Characters & Values \\
\hline \multicolumn{2}{|l|}{ Particle size distribution } \\
\hline Sand $\%$ & 72.22 \\
\hline Silt \% & 17.78 \\
\hline Clay \% & 10.0 \\
\hline Texture & sandy \\
\hline $\mathrm{pH}(1: 2.5$ extract $)$ & 8.11 \\
\hline E.C. $\left(1: 2.5\right.$ extract $\left(\mathrm{mmh}^{\circ} \mathrm{s} / 1 \mathrm{~cm} / 25^{-}{ }^{\circ} \mathrm{C}\right)$ & 0.97 \\
\hline Organic matter \% & 0.30 \\
\hline $\mathrm{CaCO}_{3} \%$ & 1.29 \\
\hline \multicolumn{2}{|l|}{ Macronutrients values } \\
\hline Total N \% & 0.09 \\
\hline P (ppm, Olsen method) & 5.1 \\
\hline $\mathrm{K}$ (ppm, ammonium acetate) & 69.9 \\
\hline $\mathrm{Mg}(\mathrm{ppm})$ & 10.9 \\
\hline \multicolumn{2}{|l|}{ EDTA extractable micronatrients (ppm) } \\
\hline $\mathrm{Zn}$ & 0.31 \\
\hline $\mathrm{Fe}$ & 0.60 \\
\hline $\mathrm{Mn}$ & 0.41 \\
\hline $\mathrm{Cu}$ & 0.22 \\
\hline
\end{tabular}

Table 2. Monthly average temperature and relative humidity \% for the two seasons of 2012 \& 2013

\begin{tabular}{lcccccccc}
\hline \multirow{2}{*}{ Month } & \multicolumn{4}{c}{$\mathbf{2 0 1 2}$} & \multicolumn{2}{c}{$\mathbf{2 0 1 3}$} \\
\cline { 2 - 9 } & \multicolumn{2}{c}{ Temperature e ${ }^{\mathbf{0}} \mathbf{C}$} & \multicolumn{2}{c}{ R.H. \% } & \multicolumn{2}{c}{ Temperature e ${ }^{\mathbf{C}}$} & \multicolumn{2}{c}{ R.H. \% } \\
\cline { 2 - 9 } & Min. & Max. & Min. & Max. & Min. & Max. & Min. & Max. \\
\hline Jan. & 7.0 & 24.2 & 31.0 & 87.0 & 6.0 & 23.2 & 29.0 & 89.0 \\
\hline Feb. & 10.1 & 28.4 & 22.0 & 69.0 & 8.1 & 23.9 & 25.0 & 84.0 \\
\hline March & 10.0 & 31.3 & 16.0 & 63.0 & 10.0 & 29.6 & 16.0 & 69.0 \\
\hline April & 15.0 & 35.1 & 14.0 & 48.0 & 16.0 & 37.3 & 13.0 & 43.0 \\
\hline May & 21.0 & 39.9 & 17.0 & 47.0 & 20.0 & 39.0 & 14.0 & 38.0 \\
\hline June & 19.0 & 39.7 & 18.0 & 61.0 & 20.1 & 40.9 & 16.0 & 53.0 \\
\hline July & 19.0 & 41.1 & 18.0 & 80.0 & 21.8 & 43.2 & 17.0 & 62.0 \\
\hline August & 20.0 & 41.3 & 21.0 & 81.0 & 20.0 & 39.8 & 22.0 & 72.0 \\
\hline Sept. & 19.8 & 40.0 & 21.0 & 73.0 & 18.8 & 40.1 & 21.0 & 71.0 \\
\hline Oct. & 18.2 & 36.4 & 25.0 & 73.0 & 13.7 & 33.7 & 23.0 & 89.0 \\
\hline Nov. & 11.3 & 31.0 & 29.0 & 93.0 & 10.2 & 29.3 & 28.0 & 91.0 \\
\hline Dec. & 7.4 & 26.3 & 30.0 & 94.0 & 7.5 & 25.1 & 28.0 & 92.0 \\
\hline RH & & & & & & &
\end{tabular}

RH \% = relative humidity \%

Source: Meteorological station

\section{L.A. $=0.70(\mathrm{~L} \mathrm{x} \mathrm{W})-1.06$}

Where L.A = leaf area $\left(\mathrm{cm}^{2}\right), \mathrm{L}$ and $\mathrm{W}=$ maximum leaf length and width $(\mathrm{cm})$, respectively. Dates of first flowering and start of fruit setting were recorded.

\section{Yield and fruit quality}

Harvesting was achieved and yield expressed in weight (kg.) was recorded. Twenty fruits from each tree were taken randomly from each tree for determining the following physical and chemical characteristics of pulp (A.O.A.C.,2000)

\section{Physical characteristics}

1- Average fruit weight (g.).

2- Average fruit length $(\mathrm{cm})$

3- Average fruit diameter $(\mathrm{cm})$

4- Average fruit thickness $(\mathrm{cm})$

5- Percentage of pulp weight

6- Percentage of seed weight. 


\section{Chemical characteristics:}

1- T.S.S. \% using hand Refractometer.

2- Total, reducing and non reducing sugars.

3- Total acidity $\%$ as g. citric acid/ $100 \mathrm{ml}$./ juice.

4- Vitamin C content as mg. / 100 g. pulp.

\section{Statistical analysis:}

All the obtained data were tabulated and statistically analyzed according to the procedure of Snedecor and Cochran, 1980. The individual comparisons among the studied parameters in the mango cvs were compared by using new L.S.D. test.

\section{ESULTS AND DISCUSSION}

\section{1- Shoot length in the three growth cycles:}

Data in Table (3) clearly show that significant differences of the shoot length in the three growth cycles were observed among the five mango cvs. It was significantly maximized in mango cv. Tommy Atkins followed by Kent and was minimized in mango cv Naomi.

Table 3. Shoot length and number of leaves in the three cycles of some mango cvs grown under Aswan governorate conditions during 2012 \& 2013 seasons

\begin{tabular}{|c|c|c|c|c|c|c|c|c|c|c|c|c|}
\hline \multirow{3}{*}{ Mango cvs } & \multicolumn{6}{|c|}{ Shoot length } & \multicolumn{6}{|c|}{ No. of leaves/ shoot } \\
\hline & \multicolumn{2}{|c|}{ Spring } & \multicolumn{2}{|c|}{ Summer } & \multicolumn{2}{|c|}{ Autumn } & \multicolumn{2}{|c|}{ Spring } & \multicolumn{2}{|c|}{ Summer } & \multicolumn{2}{|c|}{ Autumn } \\
\hline & 2012 & 2013 & 2012 & 2013 & 2012 & 2013 & 2012 & 2013 & 2012 & 2013 & 2012 & 2013 \\
\hline Kent & 10.65 & 11.45 & 11.37 & 10.20 & 13.63 & 12.83 & 10.43 & 11.60 & 8.70 & 9.16 & 12.76 & 12.70 \\
\hline Keitt & 10.52 & 10.16 & 10.91 & 9.47 & 12.60 & 11.96 & 9.40 & 9.70 & 8.46 & 8.95 & 11.40 & 11.56 \\
\hline Tommy atkins & 10.68 & 12.13 & 13.10 & 11.20 & 16.10 & 15.03 & 12.00 & 11.00 & 10.56 & 9.83 & 14.20 & 14.16 \\
\hline Heidi & 9.67 & 9.55 & 10.34 & 9.30 & 11.34 & 11.58 & 9.34 & 9.40 & 8.43 & 8.80 & 11.00 & 11.46 \\
\hline Naomi & 8.32 & 7.06 & 8.77 & 8.26 & 9.00 & 7.36 & 9.00 & 8.67 & 8.16 & 7.77 & 9.20 & 9.30 \\
\hline $\begin{array}{c}\text { New L.S.D.at } \\
5 \% \\
\end{array}$ & 0.11 & 0.10 & 0.12 & 0.12 & 0.11 & 0.10 & 1.0 & 1.0 & 1.0 & 1.0 & 1.0 & 1.0 \\
\hline
\end{tabular}

Table 4. Leaf area in the three growth cycles, date of first bloom and date of fruit setting of some mango cvs grown under Aswan governorate conditions during 2012 \& 2013 seasons

\begin{tabular}{|c|c|c|c|c|c|c|c|c|c|c|}
\hline \multirow[t]{3}{*}{ Mango cvs } & \multicolumn{6}{|c|}{ Leaf area $(\mathrm{cm})^{2}$} & \multirow{2}{*}{\multicolumn{2}{|c|}{$\begin{array}{c}\text { Date of first } \\
\text { bloom }\end{array}$}} & \multirow{2}{*}{\multicolumn{2}{|c|}{ Date of fruit setting }} \\
\hline & \multicolumn{2}{|c|}{ Spring } & \multicolumn{2}{|c|}{ Summer } & \multicolumn{2}{|c|}{ Autumn } & & & & \\
\hline & 2012 & 2013 & 2012 & 2013 & 2012 & 2013 & 2012 & 2013 & 2012 & 2013 \\
\hline Kent & 80.67 & 77.33 & 17.65 & 19.11 & 55.00 & 54.76 & $\begin{array}{c}4^{\text {th }} \text { week of } \\
\text { Jan. }\end{array}$ & $\begin{array}{l}1^{\text {st }} \text { week of } \\
\text { Feb. }\end{array}$ & $\begin{array}{c}2^{\text {nd }} \text { week } \\
\text { of Feb. }\end{array}$ & $\begin{array}{c}3^{\text {rd }} \text { week } \\
\text { of Feb. }\end{array}$ \\
\hline Keitt & 85.33 & 85.00 & 32.67 & 29.87 & 60.53 & 60.03 & $\begin{array}{l}1^{\text {st }} \text { week of } \\
\text { Feb. }\end{array}$ & $\begin{array}{l}1^{\text {st }} \text { week of } \\
\text { Feb. }\end{array}$ & $\begin{array}{c}3^{\text {rd }} \text { week } \\
\text { of Feb. }\end{array}$ & $\begin{array}{c}3^{\text {rd }} \text { week } \\
\text { of Feb. }\end{array}$ \\
\hline $\begin{array}{c}\text { Tommy } \\
\text { atkins }\end{array}$ & 89.67 & 87.00 & 36.75 & 30.65 & 63.80 & 64.23 & $\begin{array}{c}4^{\text {th }} \text { week of } \\
\text { Jan. }\end{array}$ & $\begin{array}{c}1^{\text {st }} \text { week of } \\
\text { Feb. }\end{array}$ & $\begin{array}{c}2^{\text {nd }} \text { week } \\
\text { of Feb. }\end{array}$ & $\begin{array}{c}2^{\text {nd }} \text { week } \\
\text { of Feb. }\end{array}$ \\
\hline Heidi & 68.63 & 62.00 & 16.11 & 16.01 & 38.88 & 38.50 & $\begin{array}{l}1^{\text {st }} \text { week of } \\
\text { Mar. }\end{array}$ & $\begin{array}{l}1^{\text {st }} \text { week of } \\
\text { Mar. }\end{array}$ & $\begin{array}{c}2^{\text {nd }} \text { week } \\
\text { of Mar. }\end{array}$ & $\begin{array}{c}3^{\text {rd }} \text { week } \\
\text { of Mar. }\end{array}$ \\
\hline Naomi & 74.33 & 75.00 & 20.00 & 18.15 & 42.63 & 42.90 & $\begin{array}{c}2^{\text {nd }} \text { week of } \\
\text { Feb. }\end{array}$ & $\begin{array}{l}1^{\text {st }} \text { week of } \\
\text { Feb. }\end{array}$ & $\begin{array}{l}4^{\text {th }} \text { week } \\
\text { of Feb. }\end{array}$ & $\begin{array}{c}3^{\text {rd }} \text { week } \\
\text { of Feb. }\end{array}$ \\
\hline $\begin{array}{c}\text { New L.S.D. } \\
\text { at } 5 \%\end{array}$ & 1.92 & 2.00 & 1.88 & 1.94 & 1.80 & 1.82 & - & - & - & - \\
\hline
\end{tabular}

2- Number of leaves/shoot in the three growth cycles:

Data in table (3) obviously indicate that number of leaves/ shoot in the three growth flushes were significantly differed among the five mango cvs. The maximum values were recorded in mango cv. Tommy Atkins (12.0 \& 11.0 in the spring growth cycle), (10.56 $\& 9.83$ in the summer) and (14.20 \& 14.16 in the autumn) during both seasons, respectively. The minimum values were recorded in mango cv. Naomi. These results were true during both seasons.

\section{3- Leaf area in the three growth cycles:} cvs. The highest values were recorded in mango cvs Tommy Atkins followed by Keitt, Kent, Naomi and Heidi, in descending order. The leaf area in the spring growth cycle of Tommy Atkins reached 89.67 and $\mathrm{cm}^{2}$ during both seasons, respectively. The highest values were recorded in the spring growth cycle followed by those in the autumn growth cycle. The minimum values were recorded for those leaves picked on summer growth cycle. Similar trend was noticed during both seasons (Table 4).
It was significantly varied among the five mango 


\section{4- Date of first bloom:}

It was considerably varied among the five mango cvs. The early blooming mango cvs were Kent and Tommy Atkins. They bloomed at the last week of Jan. in the first season of study and the first week of Feb. in the second season. Heidi mango cv bloomed lately at the first week of Mar. during both seasons. At the first and second weeks of Feb. mango cvs Keitt and Naomi bloomed. Similar trend was noticed during both seasons. (Table 4).

\section{5- Date of start of fruit setting:}

Data in Table(4) clearly show that majority of mango cvs began fruit setting at the periods from the second to fourth week of Feb. except mango cv Heidi which reached fruit setting stage at the second week of Mar. in the first season of study and the third week of Mar. in the second season. These results were true during both seasons.

\section{6-Panicle length:}

It is clear from the obtained data in Table (5) that panicle length was maximized in mango cv Keitt (34.97 \& $34.07 \mathrm{~cm}$ ) during both seasons, respectively. Mango cv. Tommy Atkins occupied the second position in this respect, since the values reached $(33.34 \& 33.52 \mathrm{~cm})$ during 2012 and 2013 seasons, respectively. Heidi mango cv recorded the minimum values $(26.25 \& 31.21$ $\mathrm{cm}$ ) during both seasons, respectively.

\section{7- Yield / tree:}

Data in Table(5) reveal that varying mango cvs significantly altered the yield per tree. Yield/ tree ranged from 55 to $79 \mathrm{~kg}$ in the first season and from 59 to $77 \mathrm{~kg}$ in the second season. Mango cv Keitt recorded the highest values $(79 \& 77 \mathrm{~kg})$ during both seasons, followed by Tommy Atkins (74 \& $70 \mathrm{~kg}$ ) during 2012 and 2013 seasons, respectively. The lowest values were recorded on the mango cv. Heidi ( $55 \& 59 \mathrm{~kg}$ ) during 2012 and 2013 seasons, respectively. The best four mango cvs with regard to yield were Keitt; Tommy Atkins, Kent and Naomi during both seasons.

\section{8- Fruit weight and dimensions:}

Data in Tables (5\&6) clearly show that weight,width, length and thickness of fruit were significantly varied for the five mango cvs. They were maximized in mango cvs Kent followed by Naomi, Keitt, Tommy Atkins and Heidi, in descending order .Weight, width, length and thickness of fruit were maximized in mango cv Kent. Values of weight of fruit in such mango cv. reached (554.0 \& 526.66 g.) during 2012 and 2013 seasons, respectively.

\section{9- Percentages of seeds and pulp:}

As shown in Table (6), varying mango cvs showed no significant differences on the percentages of seeds and pulp during both seasons.

\section{0- Chemical characteristics of the fruits:}

Data in Tables (6\&7) show that significant differences on all chemical characteristics of the fruits were observed among the five mango cvs.Mango cv Tommy Atkins exhibited the highest values of T.S.S. (14.93 \& 15\%), total sugars(11.52\&11.59\%), reducing sugars $(5.20 \& 5.20 \%)$, non reducing sugars $(6.34 \&$ $6.40 \%)$ and vitamin C (52.20 \& $49.03 \mathrm{mg} / 100 \mathrm{~g}$. pulp) during both seasons, respectively. Mango cv Tommy Atkins recorded the lowest values of total acidity $(0.205$ \& $0.215 \%$ ) during 2013 \& 2013 seasons, respectively. The second mango cv in this respect was Keitt. Similar trend was observed during both seasons.

The different responses of the five mango cvs to various biotic and abiotic stresses, agricultural practices, genetical aspects, growth aspects, flowering, fruit setting, harvesting dates could explain the present results.

These results are in agreement with those obtained by Ahmed (2002), Tawfik (2003), Abd El- Hadi (2006), Sayed (2009); Shaban (2009), Abourayya et al., (2011) \& (2012) and Fahmy (2016).

Table 5. Panicle length, yield / tree as well as weight, width, length of fruit of some mango cvs grown under Aswan governorate conditions during 2012 \& 2013 seasons

\begin{tabular}{|c|c|c|c|c|c|c|c|c|c|c|}
\hline \multirow[t]{2}{*}{ Mango cvs } & \multicolumn{2}{|c|}{$\begin{array}{l}\text { Panicle length } \\
\text { (cm) }\end{array}$} & \multicolumn{2}{|c|}{$\begin{array}{l}\text { Yield/ tree } \\
(\mathrm{kg} .)\end{array}$} & \multicolumn{2}{|c|}{$\begin{array}{l}\text { Av. fruit weight } \\
\text { (g.) }\end{array}$} & \multicolumn{2}{|c|}{$\begin{array}{l}\text { Fruit width } \\
\text { (cm) }\end{array}$} & \multicolumn{2}{|c|}{$\begin{array}{l}\text { Fruit length } \\
\text { (cm) }\end{array}$} \\
\hline & 2012 & 2013 & 2012 & 2013 & 2012 & 2013 & 2012 & 2013 & 2012 & 2013 \\
\hline Kent & 31.65 & 31.54 & 68.00 & 64.67 & 554.00 & 526.66 & 9.20 & 9.07 & 12.40 & 12.43 \\
\hline Keitt & 34.97 & 34.07 & 79.00 & 77.00 & 446.67 & 457.86 & 8.60 & 8.50 & 11.56 & 11.50 \\
\hline Tommy atkins & 33.34 & 33.52 & 74.00 & 70.00 & 410.00 & 400.0 & 8.43 & 8.10 & 10.50 & 10.50 \\
\hline Heidi & 26.25 & 31.21 & 55.00 & 59.00 & 353.00 & 345.00 & 7.97 & 8.00 & 10.31 & 10.27 \\
\hline Naomi & 31.53 & 32.80 & 63.00 & 61.00 & 514.00 & 475.00 & 9.00 & 9.13 & 12.10 & 12.26 \\
\hline New L.S.D. at 5\% & 1.1 & 1.0 & 2.0 & 2.1 & 15.5 & 16.0 & 0.18 & 0.15 & 0.16 & 0.17 \\
\hline
\end{tabular}


Table 6. Some physical and chemical characteristics of the some mango cvs grown under Aswan governorate conditions during 2012 \& 2013 seasons

\begin{tabular}{|c|c|c|c|c|c|c|c|c|c|c|}
\hline \multirow[t]{2}{*}{ Mango cvs } & \multicolumn{2}{|c|}{$\begin{array}{c}\text { Fruit } \\
\text { thickness }(\mathrm{cm})\end{array}$} & \multicolumn{2}{|c|}{ Seed weight \% } & \multicolumn{2}{|c|}{$\begin{array}{c}\text { Pulp weight } \\
\%\end{array}$} & \multicolumn{2}{|c|}{ T.S.S. \% } & \multicolumn{2}{|c|}{$\begin{array}{c}\text { Total sugars } \\
\%\end{array}$} \\
\hline & 2012 & 2013 & 2012 & 2013 & 2012 & 2013 & 2012 & 2013 & 2012 & 2013 \\
\hline Kent & 7.83 & 7.83 & 7.50 & 7.79 & 92.50 & 92.21 & 13.80 & 14.00 & 10.65 & 10.80 \\
\hline Keitt & 7.76 & 7.43 & 7.75 & 8.00 & 92.25 & 92.00 & 14.53 & 14.60 & 11.23 & 11.29 \\
\hline Tommy atkins & 7.10 & 7.30 & 7.80 & 8.11 & 92.20 & 91.89 & 14.93 & 15.00 & 11.52 & 11.59 \\
\hline Heidi & 6.73 & 6.70 & 7.85 & 8.15 & 92.15 & 91.85 & 13.34 & 13.73 & 10.34 & 10.60 \\
\hline Naomi & 7.73 & 7.57 & 7.60 & 7.90 & 92.40 & 92.10 & 14.00 & 14.34 & 10.82 & 11.06 \\
\hline New L.S.D. at 5\% & 0.16 & 0.18 & NS & NS & NS & NS & 0.22 & 0.21 & 0.18 & 0.17 \\
\hline
\end{tabular}

Table 7. Some chemical characteristics of the fruits of some mango cvs grown under Aswan governorate conditions during 2012 \& 2013 seasons

\begin{tabular}{lcccccccc}
\hline \multirow{2}{*}{ Mango cvs } & \multicolumn{2}{c}{$\begin{array}{c}\text { Reducing sugars } \\
\text { \% }\end{array}$} & \multicolumn{2}{c}{$\begin{array}{c}\text { Non reducing } \\
\text { sugars \% }\end{array}$} & \multicolumn{2}{c}{ Total acidity \% } & \multicolumn{2}{c}{$\begin{array}{c}\text { Vitamin C (mg/ } \\
\mathbf{1 0 0} \text { g pulp) }\end{array}$} \\
\cline { 2 - 9 } & $\mathbf{2 0 1 2}$ & $\mathbf{2 0 1 3}$ & $\mathbf{2 0 1 2}$ & $\mathbf{2 0 1 3}$ & $\mathbf{2 0 1 2}$ & $\mathbf{2 0 1 3}$ & $\mathbf{2 0 1 2}$ & $\mathbf{2 0 1 3}$ \\
\hline Kent & 4.83 & 4.84 & 5.82 & 5.97 & 0.324 & 0.322 & 42.50 & 42.83 \\
\hline Keitt & 5.10 & 5.06 & 6.13 & 6.24 & 0.228 & 0.234 & 50.10 & 46.00 \\
\hline Tommy atkins & 5.20 & 5.20 & 6.34 & 6.40 & 0.205 & 0.215 & 52.20 & 49.03 \\
\hline Heidi & 4.67 & 5.10 & 5.67 & 5.84 & 0.330 & 0.340 & 39.90 & 40.00 \\
\hline Naomi & 4.87 & 4.97 & 5.94 & 6.08 & 0.301 & 0.295 & 44.97 & 43.00 \\
\hline New L.S.D. at 5\% & 0.09 & 0.08 & 0.10 & 0.11 & 0.018 & 0.016 & 1.10 & 1.08 \\
\hline
\end{tabular}

From the obtained data it could be revealed that the five mango cvs Kent, Keitt, Tommy Atkins, Heidi and Naomi are widely varied toward their behaviour on growth and fruiting characteristics. Mango cvs Keitt, Tommy, Atkins and Kent are suggested to be cultivated successfully in descending order under Aswan conditions based on relatively better yield and fruit quality.

\section{REFERENCES}

Abd El- Hadi, S.M.K. 2006: Evaluation studies on some mango varieties . M. Sc.Thesis, Al- Azhar Univ. Egypt p. 166.

Abourayya, M.S., N.E., Kassim, M.H. El- Sheikh,. and A.M. Rakha, 2011. Fruit physical and chemical characteristics at maturity stage of Tommy Atkins, Keitt and Kent mango cultivars grown under Nubariya conditions. The J. of Amer. Sci. 7(3): 228-233.

Abourayya, M.S., N.E. Kassim, M.H. El- Sheikh, and A.M. Rakha, 2012.Evaluation of vegetative growth of Tommy Atkins, Kent and Keitt mango cultivars grown under Nubariya conditions. J. of Applied Sci. Res. ( February) 557-895.

Ahmed, A.Y.M. 2002. Morphological and biochemical studies on some mango. cultivars grown in Aswan governorate, M. Sc. Thesis Fac. Agric. Minia Univ., Egypt, 182pp.

Ahmed , F.F. and M.H. Morsy, 1999. A new method for measuring leaf area in different fruit species. Minia J. Agric. Res. Develop (19): 99. 97-104.
Association of Official Agricultural Chemists 2000. Official Methods of Analysis A.O.A.C., Benjamin Franklin Station, Washington, D.C. U.S.A.

El- Sheikh, A.F. and R.K. Burshaid, 2010. Quality evaluation of some local and imported mango cultivars grown in the United Arab Emirates. Acta Hort. (875): 365-376.

Fahmy, S.H. 2016. Evaluation studies on some mango cvs under middle Egypt conditions. M. Sc. Thesis, Fac. Agric. Al Azhar Univ. (Assiut branch)

Jilani, M. S., B. Farzana, W. Kashif,. And M.A. Kham 2010. Evaluation of physico- chemical characteristics of mango (Mangifera indica L.) cultivars grown in D.I. Khan J. Agric. Res. (Lahore): 48(2): 201-207.

Masoud, Amal, A.R. 2010. Evaluation of the productivity of some newly introduced mango cultivars under local conditions. M. Sc Thesis Cairo Univ. Fac. of Agric. Dept. of Pomology. 167 p.

Nilesh, B. and B.C. Banik, 2005. Yield and physico chemical properties of some mango cultivars in new alluvial zone of West Bengal. Environment and Ecology. 23(3): 503-506.

Pawan, K., S.Thakur, and D. Chatterjee, 2011. Evaluation of some coloured mango varieties for their flowering, fruiting and fruit quality attributes J. of Interacademica; 15(3): 382-387.

Pawan, K. and T. Surendra, 2011. Fruiting behaviour and yield attributes to some colored mango (Magnifera indica L.) varieties under Sabour (Bihar) conditions. Environment and Ecology: 29 (4): 1720-1722. 
Rao, K.D. and D.S.K. Rao, 2007. Evaluation of different vegetables as inter crops in rainfed mango orchards under laterilic soils of Andhra Pradesh. Argic. Sci. Digest; 27 (4): 295-296.

Reddy, V.S. H.B., Lingaiah, K.S. Krishnappa, V., Shankaranarayana, P. Venkataramana, and M.N.N. Reddy,. 2011. Evaluation of mango varieties for the eastern dry zone of Karnataka, Mysore J. of Agric. Sci. 45 (1): 107-110.

Safuna, N., M.A. Anjum, C., Sobia, A. Saeed, and S. Bushra, 2014. Physico - chemical and sensory profilluing or promising mango cultivars grown in peri- urban areas of Multan. Pakistan. Pakistan J. of Botany: 46(1): 191-198.

Sayed, S.A. 2009. Evaluation of mango cultivars for productive and commercial plantation under Punjab conditions of Pakistan. Acta Hort. 820: 147-151.

Shabam A.E.A. 2009. Vegetatiev growth cycles of some mango cultivars in relation to flowering and fruiting World Journal of Agricultural Sciences; 5(6)751-759.
Swidan, A.M. M.M., Khattab, G.M. Haseeb, and M.A. ElKheshin, 2007. Evaluation of some mango cultivars under desert conditions at Wadi El- Faregh region Egypt, J. Appl. Sci. 22 (8A) : 149-160.

Snedecor, G.W. and W.G. Cochran 1980.Statistical methods $6^{\text {th }}$ ed. The Iowa State Univ. Press Ames Iowa U.S.A. pp. 593.

Tawfik, E.S.B. 2003. Evaluation of some export mango cultivars grown in Egypt. Ph. D. Thesis Assiut Univ. Egypt. 187p.

Wang, S., Wu, H. Zma, W. Ma. X. Zhan, R. Yao. O. Sun, G. And Xie, J. 2013. Evaluation of sixteen introduced mango cultivars in Zhanjiang China Acta Hort. 992: 211-219.

Wilde, S.A., R.B., Corey, J.G. Layer, and G.K. Voigt. 1985. Soils and Plant Analysis for Tree Culture. Oxford IBH, New Delhi, India.

Zaied, N.S., S.A.A. Khafagy, and M.A. Saleh. 2007. Evaluation of some mango species by fruit characters and fingerprint. Research J. of Agric and Bio. Sci. 3(4): 316320.

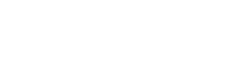

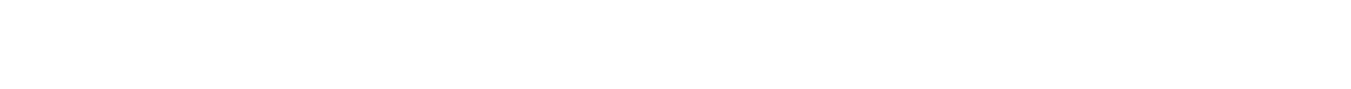

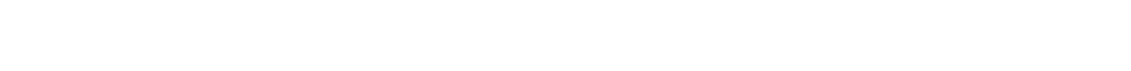

واعتمادا على كمية المحصول المرقفعة وخ صائص

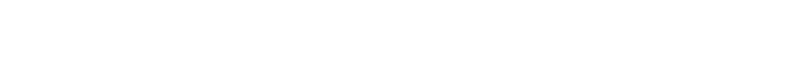

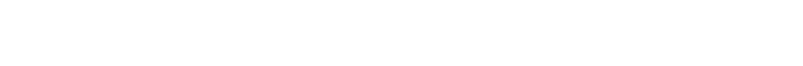
مطفة لسوان. الكلملت الدالة: أصنف المانجو - النمو - الاثمار
مُ ققيم نمو وكمية محصول وجولة ثمار خمسة الصنف

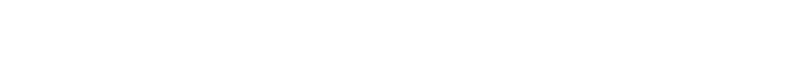

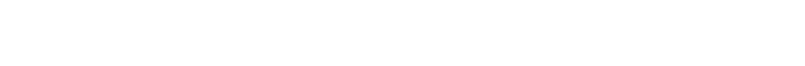

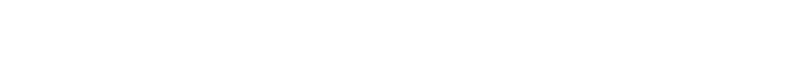
وخصائص الاثمار بين الصنف المانجو الخمسة. 